\title{
Membership announcement
}

\section{Meeting with a lecture by professor Carl-Henrik Heldin followed by dinner}

TIME: September $18^{\text {th }}, 20195.30 \mathrm{pm}$

PLACE: Gunne Hall, University Hospital entrance 10, Uppsala

HOUR: 17:30

Professor Heldin is a molecular biologist and medical researcher. He was appointed director of the Uppsala branch of Ludwig Cancer Research 1986 and professor in molecular cell biology at the medical faculty of Uppsala University 1992. He is the chairman of the Nobel Foundation sicne 2013. His research has focused on the mechanisms of signal transduction by growth regulatory factors like platelet-derived growth factor (PDGF) and transforming growth factor (TGF).

The best dissertation during the academic year 2018- 2019 will be awarded.

After the meeting the members are invited to dinner at 19:00 in the Orangerie in the Linnean Garden, Uppsala. Please use the e-mail Anna.Rask-Andersen@medsci.uu.se for registration for the dinner or call +46704250654 . Please indicate any food allergies.

\section{The Olof Rudbeck Day}

TIME: October $18^{\text {th }}, 2019$

PLACE: Grönwall Hall, University Hospital entrance 70, Uppsala.

HOUR: 9:00 - 15.45

This year's theme will be autoimmunity. You will find the program here: https://www.medfarm.uu.se/rudbeckdagen/

\section{A warm welcome to all our members of Upsala Society of Medicine!}

